\title{
RF induced heating of pacemaker/ICD lead-tips during MRI Scans at 1.5T and 3T: evaluation in cadavers
}

\author{
Volkan Acikel ${ }^{2 *}$, Patrick Magrath ${ }^{2,1}$, Scott E Parker ${ }^{2}$, Peng Hu², Holden $\mathrm{H} \mathrm{Wu}^{2}$, J Paul Finn², Daniel B Ennis ${ }^{2,1}$ \\ From 19th Annual SCMR Scientific Sessions \\ Los Angeles, CA, USA. 27-30 January 2016
}

\section{Background}

Studies about the safety of MRI exams for patients with pacemakers/ICDs at 1.5T have been reported [Nazarian S., et al. Annals of internal medicine 155.7 (2011): 415-424.]. Of most concern is possible heating of the lead-tips in contact with the myocardium. Little is known about the relative safety of 3T MRI exams for these patients and in vivo lead-tip heating data is difficult, if not impossible, to obtain. Our objective was to measure lead-tip heating directly in human cadavers with pacemakers/ICDs at both 3.0 T and 1.5T.

\section{Methods}

Cadavers $(\mathrm{N}=5$, 3 male, Table 1, part 1$)$ with existing pacemakers had fiberoptic temperature probes implanted adjacent to right atrial (RA), right ventricular (RV) and/or abandoned lead-tips under x-ray guidance. Whole-body
CT was used to estimate lead-tip to probe-tip distances. Cadavers were exposed to 15 -minutes of $4 \mathrm{~W} / \mathrm{kg}$ whole body SAR at both $1.5 \mathrm{~T}$ and $3 \mathrm{~T}$ (Siemens Avanto and Prisma) for five isocenter positions: $6 \mathrm{~cm}$ superior to the chin $\left(\mathrm{LM}_{1}\right)$ and in four $15 \mathrm{~cm}$ increments inferior to $\mathrm{LM}_{1}$ $\left(\mathrm{LM}_{2}\right.$ to $\left.\mathrm{LM}_{5}\right)$ in order to evaluate lead-tip heating as a function of the device's position relative to isocenter (i.e. different MRI exams). Maximum temperature increases at the lead-tip were reported as $\Delta \mathrm{T}_{\mathrm{Max}}$ (temperature difference between the baseline before the MRI sequence and peak heating after 15 -minutes).

\section{Results}

All temperature probes were $\leq 10 \mathrm{~mm}$ from the lead-tip (Table 1, part 2). Figure 1 shows $\Delta \mathrm{T}_{\mathrm{Max}}$ for $1.5 \mathrm{~T}$ and $3 \mathrm{~T}$ for each probe. Maximum heating was observed at the $\mathrm{LM}_{2}$ and $\mathrm{LM}_{3}$ isocenter positions for which the whole

Table 1 Part 1 is the table that shows vital statistics of the cadavers. Part 2 is the table that shows the lead tip to probe tip distances

\begin{tabular}{|c|c|c|c|c|c|c|c|c|}
\hline Part 1 & Gender & Weight (kg) & $\begin{array}{l}\text { Height } \\
(\mathrm{cm})\end{array}$ & BMI & Age & & & \\
\hline Cadaver 1 & Male & 54 & 167 & 19.4 & 93 & & & \\
\hline Cadaver 2 & Female & 36 & 147 & 16.7 & 99 & & & \\
\hline Cadaver 3 & Male & 58 & 177 & 18.5 & 85 & & & \\
\hline Cadaver 4 & Male & 45 & 172 & 15.2 & 93 & & & \\
\hline Cadaver 5 & Female & 68 & 167 & 24.4 & 87 & & & \\
\hline Part 2 & $\begin{array}{c}\text { Cadaver } \\
1\end{array}$ & $\begin{array}{c}\text { Cadaver } 2 \text { RA } \\
\text { lead }\end{array}$ & Cadaver 3 & $\begin{array}{c}\text { Cadaver } 4 \text { RA } \\
\text { lead }\end{array}$ & $\begin{array}{c}\text { Cadaver } 4 \text { RV } \\
\text { lead }\end{array}$ & $\begin{array}{c}\text { Cadaver } 5 \text { RA } \\
\text { lead }\end{array}$ & $\begin{array}{c}\text { Cadaver } 5 \text { RV } \\
\text { lead }\end{array}$ & $\begin{array}{c}\text { Cadaver } 5 \\
\text { Abandoned lead }\end{array}$ \\
\hline $\begin{array}{l}\text { Lead tip to probe tip } \\
\text { distance }\end{array}$ & $6.4 \mathrm{~mm}$ & $3.4 \mathrm{~mm}$ & $10 \mathrm{~mm}$ & $2 \mathrm{~mm}$ & $9 \mathrm{~mm}$ & $6.5 \mathrm{~mm}$ & $7.6 \mathrm{~mm}$ & $4 \mathrm{~mm}$ \\
\hline
\end{tabular}

${ }^{2}$ Department of Radiological Sciences, University of California Los Angeles,

Los Angeles, CA, USA

Full list of author information is available at the end of the article 

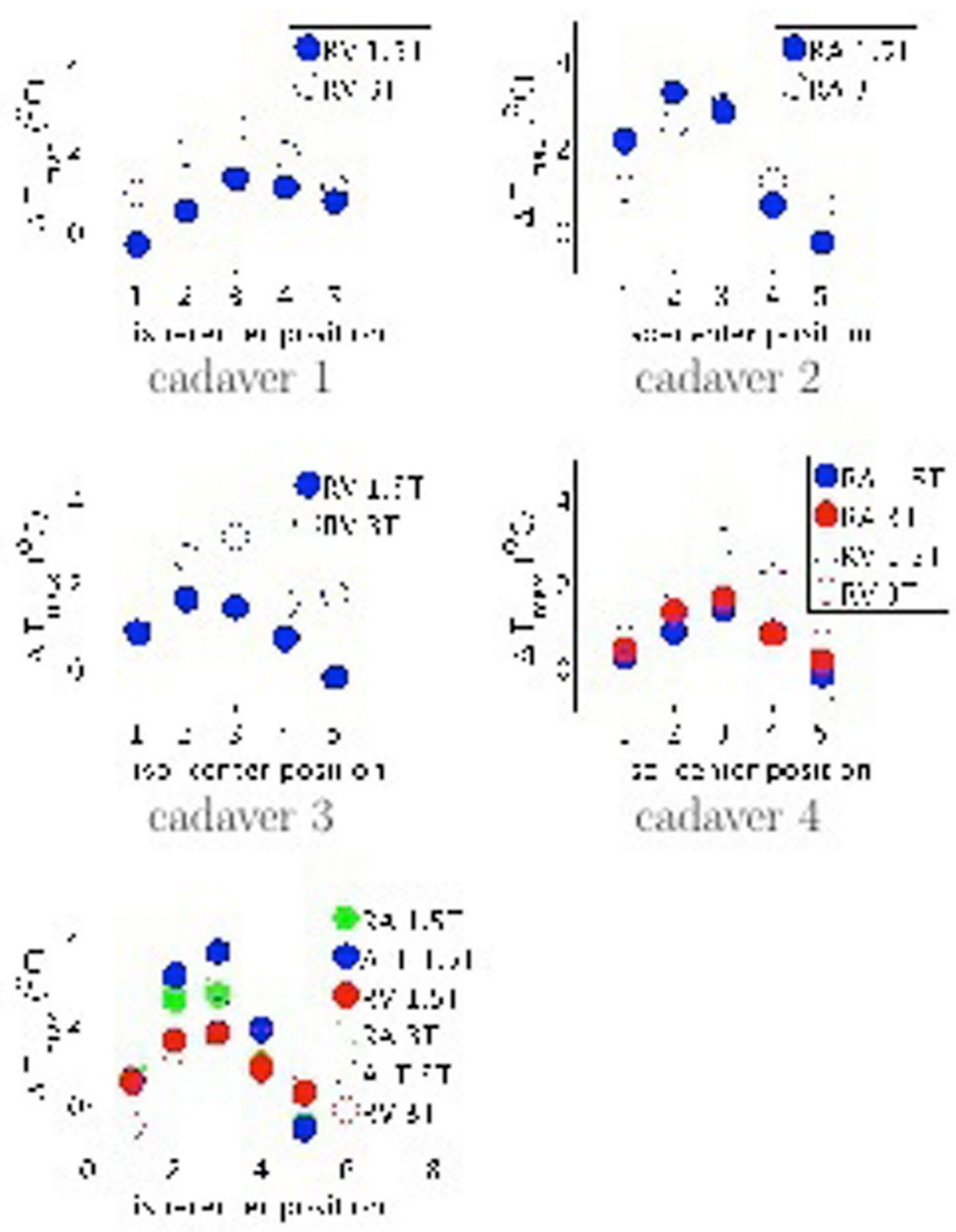

\section{cadaver 5}

Figure $1 \Delta \mathbf{T}_{\text {Max }}$ for each isocenter position. Cadavers 1 and 3 have single chamber pacemakers (RV leads); cadavers 2, 4, and 5 have dual chamber pacemakers (RA and RV lead). Cadaver 5 also had 10 abandoned leads. For single chamber pacemakers a temperature probe was placed at the lead-tip and the remaining temperature probes were placed in remote tissue for reference. For dual chamber pacemakers, the temperature probes were placed at the RA and RV lead-tips and two probes were placed in remote tissue for reference. For the cadaver with abandoned leads two temperature probes were placed close to the lead-tips connected to the pacemaker and one probe was placed close to lead-tip of one abandoned lead (ALT). Note that in cadaver 2 the RV temperature probe was not close enough to the RV lead-tip (accidentally partially withdrawn) to obtain temperature data. 
implant was inside the body transmit coil. $\Delta \mathrm{T}_{\text {Max }}$ was $>2 \mathrm{C}$ for 7 of 25 cases at $1.5 \mathrm{~T}$ and for 12 of 25 cases at $3 \mathrm{~T}$, but never exceeded $4 \mathrm{C}$.

\section{Conclusions}

These data do not indicate a substantial difference between lead-tip heating at $1.5 \mathrm{~T}$ and $3 \mathrm{~T}$, nor do they indicate $\triangle \mathrm{T}_{\text {Max }}>4 \mathrm{C}$ despite the lack of cooling due to tissue perfusion. Continued evaluation is warranted and on-going.

\section{Authors' details}

'Department of Bioengineering, University of California Los Angeles, Los Angeles, CA, USA. ${ }^{2}$ Department of Radiological Sciences, University of California Los Angeles, Los Angeles, CA, USA.

Published: 27 January 2016

doi:10.1186/1532-429X-18-S1-0121

Cite this article as: Acikel et al:: RF induced heating of pacemaker/ICD lead-tips during MRI Scans at 1.5T and 3T: evaluation in cadavers.

Journal of Cardiovascular Magnetic Resonance 2016 18(Suppl 1):0121.

Submit your next manuscript to BioMed Central and take full advantage of:

- Convenient online submission

- Thorough peer review

- No space constraints or color figure charges

- Immediate publication on acceptance

- Inclusion in PubMed, CAS, Scopus and Google Scholar

- Research which is freely available for redistribution

Submit your manuscript at www.biomedcentral.com/submit 